\title{
ISSUES AND CHALLENGES USE OF FROG VLE IN SCIENCE LEARNING
}

\author{
Titik Rahayu', Syafrimen Syafril ${ }^{2}$, Mohamed Yusoff bin Mohd Nor ${ }^{1}$, Agus Pahrudin², Nur \\ Rohmatul Aini ${ }^{2}$, Vicka Puspasari ${ }^{2}$ \\ ${ }^{1}$ Fakulty of Education, Universiti Kebangsaan Malaysia, 43600 UKM Bangi, Selangor, Malaysia \\ ${ }^{2}$ Universitas Islam Negeri Raden Intan Lampung, Jl. Letkol H. Endro Suratmin, Sukarame, \\ Bandar Lampung, Indonesia \\ *Corresponding author: syafrimen@radenintan.ac.id
}

Tel.: +6281374576227

Fax: $+\underline{62721780887}$

\begin{abstract}
Frog Virtual Learning Environment (Frog VLE) is one of the supporting learning applications utilizing Information and Communication Technology (ICT) in $21^{\text {st }}$-century science learning. This paper concept tries to look at various issues in using VLE Frog to carry out science learning activities. Some previous studies were analyzed in depth for this purpose. The results of the analysis show that Frog VLE has not been widely used to support teacher science learning. In fact, the VLE Frog needs to be given a serious support to add to the process of learning science in the future, the teacher must be given continuous and consistent training in the use of the Frog VLE in the process of learning science.

Keywords: Virtual learning environment, Science learning activities, Continuous training, serious support, process of learning science.
\end{abstract}




\section{A. INTRODUCTION}

Teachers are the facilitators who play a role in realizing the learning objectives in school (Rasul, Ismail, Ismail, Rajuddin, \& Rauf, 2009). To meet those needs teachers have to create a learning environment in the classroom (Oluwatumbi, 2015). One of the current challenges of learning is related to the effectiveness, quality and suitability of various information technology resources in learning (KPM, 2013). To address these challenges, teachers need to improve their knowledge, and competence continuously to keep up-to-date with current and future learning needs.

The current educational process occurs in digital zones and differs from previous demands, the use of technology as the backbone of an inevitable learning (Iberahim, Mahamod, \& Mohamad, 2017). Therefore, these requirements are an urgent adjustment for teachers (Uche, Chineze, Kaegon \& Chiemezie, Okata, 2016). He suggested that some of the skills needed by teachers nowadays are critical thinking and problem solving, communication, collaboration, creativity and innovation, information, media and technology skills, initiatives and self-direction, cultural capabilities, productivity and accountability, leadership and responsibility. The skill in using technology to connect with students is one of the inevitable skills (Iberahim et al., 2017). For that reason, teachers need guidance on using technology to be used safely and effectively (Boholano, 2017).

The use of technology in developing countries is a new phenomenon (Adegbenro, Gumbo, \& Olakanmi, 2017), and is an important skill for teachers to improve teaching and learning (J. B. Adegbenro, M. T. Gumbo, \& E. E. Olakanmi, 2017). In Europe, these skills are called e-skills related to efficiency, ability to develop, and use technology in the context of the knowledge environment (Z. Mitrovic, Sharif, M, Taylor, \& Wesso, 2012). The importance of technology can be used for the development of various civil and business society activities (Z. Mitrovic, Sharinf, \& Taylor, 2012). Therefore, teachers need to be proficient in using technology to create an effective learning process. Adegbenro, Gumbo, and Olugbara (2015) Stated that process functions, content, and effective pedagogical knowledge can be done by using technology.

Previous studies have shown that the use of technology in learning is influenced by the attitude of teachers in the use of technology (Chigona \& Chigona, 2010). Marcos, Gonzales, and GuanLin (2012) found that teachers' attitude was very positive towards the use of technology in 
learning, although there were still many challenges in integrating technology into learning in school. Challenges are (i) leadership support, inconsistent investments, infrastructure and resources, additional professional development requirements and support also, technology setting in the assessment and curriculum (Rabah, 2015). The integration of technology into teaching can provide diverse teaching, enabling students to be more autonomous, more cooperative in learning, while information and resources related to the needs and interests of students all contribute to the degree of involvement of students on the use of technology in learning (Rabah, 2015) (Rabah, 2015).

KPM (2013) has introduced an e-learning system through a virtual learning environment (VLE) in nearly ten thousand primary and secondary schools (Ali, 2015). The KPM initiative encourages the use of technology to create a more efficient learning environment for teachers, parents, and students (Baharudin \& Mansor, 2010). Frog VLE is a web-based system that resembles a real-world education, by integrating conventional education in a virtual environment. In the Frog VLE web, teachers can upload songs, videos, pictures, exercises in Microsoft word, power point, forum and chatroom to interact (Ashikin, Ibrahim, \& Osman, 2013; Zurina Hamid \& Sanitah Mohd Yusof, 2014).

Guidance in developing multimedia-based teaching media that can give maximum impact in the learning process (Rafiza \& Maryam, 2013). Teachers need to use Frog VLE maximum based on a guideline based on the pedagogical and theoretical aspects of the application (Kasim \& Tasir, 2014). In addition, Frog VLE in learning has a positive effect, namely (i) positive impact on student achievement in terms of effectiveness as a student, improving learning quality and as a tool in the course, (ii) self-reliance learning, (iii) to learn in terms of feedback on student activities and to encourage collaborative communication and learning through forums, chat and e-mails for discussion (Jenny \& Peter, 2013).

The integration of technology in the learning process has a positive impact on the achievement of students (Abdulahi, NorHidayati, \& Elmi, 2012; Songkram, 2015), to enhance the achievement of learning goals (Mohd Azli \& Abdul Latif, 2012). While the learning process using the Frog VLE platform is an approach to addressing the diversity of learning styles in producing a positive impact on student skills (Mohd Azli, Wong, \& Goh, 2016). The advantages of this learning approach still fail to attract teachers to use Frog VLE as the main learning 
platform in the school (Mahizer \& Mohd Azli, 2016). This paper explores the issues, challenges, and implications of Frog VLE's use of learning activities.

\section{B. ISSUES AND CHALLENGES OF USING FROG VLES IN SCIENCE LEARNING}

To meet the challenges of education 2013-2025 has outlined the 7th shift in technology utilization to improve the quality of learning in Malaysia (Noraini et al., 2015), one of which is the use of Frog VLE in learning. Among the challenges in the use of Frog VLE is the integration of technology with learning (Adegbenro et al., 2015; Flanagan \& Shoffner, 2011), and lack of training for teachers in service (J. B. Adegbenro, P. M. T. Gumbo, \& E. E. Olakanmi, 2017). From these challenges, schools need to encourage teachers to have the skills in the use of technology in school.

The use of ICT in schools has not reached a high level, either in terms of quality or quantity (Kasim \& Tasir, 2014). Teachers are less likely to use Frog VLE for lack of knowledge and not enough time to prepare learning materials through Frog VLE (Shahaimi \& Khalid, 2015). Mohiddin and Khalid (2014) state that $2 \%$ of the teachers use Frog VLE in learning. The majority of teachers only use VLE as a repository for students to acquire learning materials such as PowerPoint and reading lists (Rienties, Giesbers, Lygo-Baker, Ma, \& Rees, 2016). Teachers' awareness of working in the 21 st century and the lack of encouragement for teachers from the school to use technology in teaching in the classroom environment is also an issue (Uche \& Chiemezie, 2016).

Other researchers have also found that the use of technology in private schools, in some cases it is almost nonexistent (Hew \& Kadir, 2016). In terms of school facilities it is found that the main factor of teachers lacking using technology in the learning process is related to the number of computers (Boon \& Ngatimin, 2011). Most rural schools have problems with the internet, networks, technical support, lack of effective training, limited time and lack of teachers efficiency, so the use of Frog VLE has not been fully achieved (Ghavifekr, Kunjappan, Ramasamy, \& Anthony, 2016). Parents should be more open-minded to provide internet facilities, and have a computer at home to improve student performance in technology (Hazura 
Mohamed, Noor, \& Yusof, 2012). However, the issue in fulfilling the needs of students is very much related to parents' income.

Issues that occur outside Malaysia are similar to Malaysian issues, which are related to the weaknesses in using ICT because teachers are limited in knowledge, databases, video conferencing tools, and learning management tools such as blackboards in their teaching practices (J. B Adegbenro et al., 2017). In addition, Adegbenro et al. (2015) and Flanagan and Shoffner (2011) stated that in general teachers are troubled with self-confidence for using ICT in PdP, teachers are confident with their basic skills but are less confident in handling some technical applications. This is due to several factors, namely (i) restricted access and network connections, (ii) schools with limited technical support, (iii) lack of effective training, (iv) limited time, and (v) lack of teacher competencies (Ghavifekr et al., 2016). Teachers in urban areas are believed for ICT usage and ICT access are higher than rural teachers. The study Haji and Park (2017) found that there was no significant difference in the use of public or private ICT, access to ICT, competence and training support.

From some studies that have stated above, it can be concluded that there are various internal and external factors that barrier to integrating ICT in the form of Frog VLE in school. Some factors that prevent teachers from integrating ICT into school are confidences or competencies towards ICT, access to ICT, training teachers, time, and technical support issues (J. B Adegbenro et al., 2017; Flanagan \& Shoffner, 2011). In addition, school principals also play a role.. Noraini, Mohd. Izham, and Mohd Izham Bin Mohd Hamzah (2015) found that there were still gaps in technology integration in schools because of lack of school principal's proficiency in managing human resources and technology in schools.

\section{RECOMMENDATIONS AND IMPLICATIONS}

Frog's VLE learning in school not only supports e-learning activities such as information dissemination, course material handling, and evaluation. Learning Frog VLE can provide rich media environments with various graphics, videos, animations, and sounds (Berns, GonzalezPardo, \& Camacho, 2013). Supported by Georgouli, Skalkidis, Guerreiro, and Pedro (2008) and 
Cheok, Wong, and Ayub (2017) studies the Frog VLE can increase the interest of teachers and students, and improve teaching effectiveness, cost savings, and improve traditional learning. According to Thah (2014) through Frog VLE's learning the teacher can set lessons, tests and scores. While students can do the homework, see notes and important documents related to learning. Additionally, school administrators can organize their calendar and disseminate notifications via Frog VLE.

From the many issues that have been raised, some of the suggestions that can be shared to supplement the teaching of Frog VLE are (i) teachers need to be practiced using ICT properly in order to get accustomed and to add ICT skills (J. B Adegbenro et al., 2017). Marcos et al. (2012) stated that for the successful implementation of intervention programs, teachers competencies need to be carefully considered in the planning and implementation of ICT integration programs. There should be ongoing efforts to address the various issues as previously shown. Teachers are allowed to form self-development groups by involving more competent partners in the field of technology, as well as having professional development programs, and are encouraged to use ICT-based teaching and learning strategies (Uche \& Chiemezie, 2016).

School administrators need to clear the objective of virtual learning implementation, and the plans for involving all school students and parents need to be developed. Skills upgrading programs need to be set up to ensure that only interested and skilled teachers are active in the implementation, monitoring should be carried out, feedback on implementation should be collected and assessed for improvement purposes, re-evaluate plans based on feedback and improve implementation strategies (Ghavifekr, Afshari, M \& Amla, 2012). Internet access needs to be increased, teacher workloads are reduced and teachers need to change their minds, make early teaching planning and be prepared to attend organized courses related to Frog VLE applications (Abdullah et al., n.d.).

According to Cheok et al. (2017) the steps that can be used to maintain and enhance digital-based learning are to know the situation faced by teachers. Thus, schools need to provide the right way to improve teachers' professionalism in technology. In addition, teachers benefit from improving classroom-based learning (Cheok et al., 2017). Frog VLE is very important for educational institutions because it affects the quality of learning. Frog VLE's teaching has so far emphasized the features, components and technical aspects of optimizing the use of Frog VLE in 
the classroom (Sa'don, Dahlan, \& Zainal, 2013). Teachers are at the forefront, so training and support for teachers are an important component of e-learning education. Hence, continuous training is required (Kaur \& Hussein, 2014).

\section{CONCLUSION}

The master and the use of ICT is a symbol of the current era. One of the ICTs is the Frog VLE (Virtual Learning Environment) web-based system, which greatly facilitates the learning process. It is undeniable that technology has become a major supplement in the education world today. Thus, the learning process runs more easily and effectively with the use of IT. Therefore, it should be given special attention to improving the skills of teachers in facing current challenges and making the education process more meaningful.

\section{E. ACKNOWLEDGEMENT}

I express my deepest gratitude to my teacher Syafrimen, M. Ed, Ph. D, for sincerity and patience to guide me in writing this article. Thank you for being willing to read and give suggestions and improve the content of articles that are less precise and clear. I also say thank you to Dr. Mohamed Yusoff bin Mohd Nor as the teacher in the subject (Educational Issues in Malaysia), so I took the initiative and was challenged in writing this article.

\section{REFERENCE}

Abdulahi, A. A., NorHidayati, Z., \& Elmi, A. H. (2012). An Evaluation of Virtual Learning Environment Readiness in Higher Education Institutions (HEIs). Journal of Information Systems Research and Innovation, 2, 86 - 94.

Adegbenro, B. J., Gumbo, M. T., \& Olugbara, O. O. (2015). Exploring technological knowledge of Office Data Processing teachers: Using factor analytic methodology. In M.L. Niess \& H. Gillow-Wiles (eds.), Handbook of research on teacher education in the digital age. 
Adegbenro, J. B., Gumbo, M. T., \& Olakanmi, E. E. (2017). In-Service Secondary School Teachers' Technology Integration Needs in an ICT-Enhanced Classroom TOJET: The Turkish Online Journal of Educational Technology, 16(3).

Adegbenro, J. B., Gumbo, P. M. T., \& Olakanmi, E. E. (2017). In-Service Secondary School Teachers ' Technology Integration Needs in an ICT- Enhanced Classroom. 16(3), 79 87.

Baharudin, F. B., \& Mansor, A. N. (2010). Aplikasi Projek Loff Vle Frog Dalam Aktiviti Pembelajaran Abad Ke-21.

Berns, A., Gonzalez-Pardo, A., \& Camacho, D. (2013). Game-like language learning in 3-D virtual environments. Computers \& Education, 60(1), 210-220.

Boon, Y., \& Ngatimin, S. (2011). Penggunaan Makmal Komputer Dalam Kalangan Guru-Guru Sekolah Kebangsaan Zon Jementah, Daerah Segamat Dalam Pengajaran Dan Pembelajaran : Satu Tinjauan Journal of Technical, Vocational \&Engineering Educational, 3, 132-147

Cheok, M. L., Wong, S. L., \& Ayub, A. F. (2017). Teachers' perceptions of e-learning in Malaysian Secondary Schools. Malaysian Online Journal of Educational Technology (MOJET), 5(2), 14.

Chigona, A., \& Chigona, W. (2010). An investigation of factors affecting the use of ICT for teaching in the Western Cape schools Paper presented at the ECIS 2010 Proceedings, Pretoria, South Africa.

Flanagan, S., \& Shoffner, M. (2011). Two teachers' technology use: Recommendations for English teacher preparation. Research highlights in technology and teacher education. Society for Information \& Teacher Education. USA.

Georgouli, Skalkidis, K., Guerreiro, I., \& Pedro. (2008). A Framework for Adopting LMS to Introduce e-Learning in a Traditional Course. Educational Technology \& Society, 11(2), 227-240.

Ghavifekr, S., Kunjappan, T., Ramasamy, L., \& Anthony, A. (2016). Teaching and Learning with ICT Tools: Issues and Challenges from Teachers' Perceptions. Malaysian Online Journal of Educational Technology, 4(2), 38 - 57.

Haji, S. A., \& Park, I. (2017). Teachers ' Use of Information and Communications Technology in Education : Cameroon Secondary Schools Perspectives. 16, 3, $147-153$. 
Hazura Mohamed, H. M. J., Noor, S. F. M., \& Yusof, Z. M. (2012). Jurang Digital dan Pendidikan di Luar Bandar: Tahap Literasi Teknologi Maklumat dan Komunikasi Pelajar. Asia Pacific Journal of Information Technology and Multimedia Jurnal Teknologi Maklumat dan Multimedia Asia Pasifik, 1(2).

Hew, T. S., \& Kadir, S. L. S. A. (2016). Understanding cloud-based VLE from the SDT and CET perspectives: Development and validation of a measurement instrument. Computers \& Education, 101, 132-149.

Iberahim, A. R., Mahamod, Z., \& Mohamad, W. M. R. W. (2017). Pembelajaran Abad Ke-21 Dan Pengaruhnya Terhadap Sikap, Motivasi Dan Pencapaian Bahasa Melayu Pelajar Sekolah Menengah. Jurnal Pendidikan Bahasa Melayu -JPBM (Malay Language Education Journal-MyLEJ), 7(2), 77-88.

Jenny, B., \& Peter, G. (2013). The learning impact of a virtual learning environment: students' views. Teacher Education Advancement Network Journal (TEAN), 5(2), 19-38.

Kaur, T., \& Hussein, N. (2014). Teachers' readiness to utilize Frog VLE: A case study of a Malaysian secondary school. Journal of Education, Society \& Behavioral Science, 5(1), 20-29.

Kementerian Pendidikan Malaysia. Pelan Pembangunan Pendidikan Malaysia 2013-2025, (2013).

Marcos, A. B. S. J. J. M., Gonzales, M., \& GuanLin, H. (2012). In service Teachers' Attitudes Toward The Use of ICT in the Classroom. Social and Behavioral Sciences, 46, $1358-$ 1364. doi:10.1016/j.sbspro.2012.05.302

Mitrovic, Z., Sharif, M, Taylor, W., \& Wesso, H. (2012). Systemic Approach to e-Skilling in South Africa. Paper presented at the Informing Science + IT Educaton Conference (InSITE 2012), Jun 22 - 27, 2012, Montreal, Canada.

Mitrovic, Z., Sharinf, M., \& Taylor, W. W., H. (2012). Systemic approach to e-skilling in South Africa. International Journal of Education and Development using Information and Communication Technology (IJEDICT), 9(3), 103-123.

Mohd Azli, Y., \& Abdul Latif, G. (2012). Kesan pendekatan pembelajaran berasaskan projek berteraskan teknologi terhadap pencapaian dan penerimaan pelajar. Jurnal Pendidikan Bitara UPSI, 5, 44-61. 
Mohd Azli, Y., Wong, K., \& Goh, P. S. C. (2016). Blended learning: pedagogy, learning styles, and assessment activities in the classroom. International Journal of Advanced and Applied Sciences, 3(11), 36-39. doi:http://doi.org/https://doi.org/10.21833/ijaas.2016.11.007

Mohiddin, U. S., \& Khalid, F. (2014). Tahap Pengetahuan Guru Sekolah Rendah dalam penggunaan VLE FROG untuk pengajaran \& pembelajaran. Paper presented at the The 4th International Conference on Learner Diversity (ICELD 2014).

Noraini, A., Hamidon, K, Mohd. Izham, M. H., Binti Abdullah, N, Bin Khalid, H, \& Mohd Izham Bin Mohd Hamzah, M. (2015). Amalan Kepimpinan Teknologi Pengetua dalam Pengintegrasian ICT di Sekolah Menengah. 3rd Global Summit on Education, 684 - 694.

Rafiza, A. R., \& Maryam, A. R. (2013). Pembinaan Media Pengajaran berasaskan Multimedia di kalangan Guru ICTL. Jurnal Kurikulum \& Pengajaran Asia Pasifik, 1, 20-31.

Rasul, M. S., Ismail, M. Y., Ismail, Rajuddin, R., \& Rauf, R. A. (2009). Aspek kemahiran 'employability' yang dikehendaki majikan industri pembuatan masa kini. Jurnal Pendidikan Malaysia, 34(2), 67-79.

Rienties, B., Giesbers, B., Lygo-Baker, S., Ma, H. W. S., \& Rees, R. (2016). Why some teachers easily learn to use a new virtual learning environment: a technology acceptance perspective. Interactive Learning Environments, 24(3), 539-552.

Sa'don, N. F. B., Dahlan, H. B. M., \& Zainal, H. B. (2013). Derivation for design of Virtual Learning Environment (VLE) framework for Malaysian schools. In Research and Innovation in Information Systems (ICRIIS). Paper presented at the International Conference on IEEE.

Shahaimi, S., \& Khalid, F. (2015). Persekitaran Pembelajaran Maya Frog (VLE-FROG) Di Sekolah-Sekolah Di Malaysia: Pelaksanaan Dan Cabaran. Paper presented at the Prosiding Seminar Kebangsaan Pendidikan Negara Kali Ke-5.

Songkram, N. (2015). E-learning System in Virtual Learning Environment to Develop Creative Thinking for Learners in Higher Education. Procedia - Social and Behavioral Sciences, $174,674-679$.

Thah, S. S. (2014). Leveraging Virtual Learning Environment to Scale Up Quality Teaching and Learning in Malaysia. Asia-Pacific Collaborative education Journal, 10(1), 1-17. 
Uche, C., Kaegon, L, \& Chiemezie, O., F. (2016). Teachers' Level of Awareness of 21st Century Occupational Roles in Rivers State Secondary Schools. Journal of Education and Training Studies, 4(8). 